\title{
COMMENTARY
}

\section{Good and bad fever}

\author{
Jean-Marc Cavaillon* \\ See related research by Egi et al., http://ccforum.com/content/16/1/R33
}

\begin{abstract}
Fever is considered a key actor of innate immunity aimed to fight infection. A new investigation reports an association of the use of antipyretic drugs with poorer outcome among patients with sepsis. In contrast, high temperature in non-infectious intensive care patients is associated with higher mortality.
\end{abstract}

The report by Egi and colleagues offers new insight into the association between fever and outcome in ICU patients with or without sepsis [1].

Fever has been recognized as a hallmark of diseases for 4,500 to 5,000 years - as mentioned in the Edwin Smith papyrus (about $1600 \mathrm{BC}$ ), a copy of a much older document (3000 to $2500 \mathrm{BC}$ ). Later, the Greeks confirmed the Egyptian's observations as can be seen in the Corpus Hippocraticum (fifth to fourth century BC). However, quantifying this observation took another 2,000 years. This quantification first required defining normal temperature in humans. John Davy (1790 to 1868), a British medical doctor, was probably the first to record temperature in healthy individuals during his 1816 to 1818 journey from England to Ceylon [2]. With the use of a pyrometer, French physicist Antoine Becquerel (1788 to 1878) confirmed in 1835 the normal temperature range in healthy people [3].

Fever is due to a number of endogenous molecules able to modify the regular temperature. While the activity of pyrexin described by Menkin was possibly due to an endotoxin contamination [4], the fever-producing substance from polymorphonuclear leukocytes of Bennett and Beeson [5] and the endogenous pyrogen of Atkins and Wood [6] were sound candidates, now recognized as pyrogenic cytokines. Many inflammatory cytokines, including IL-1, TNF and IL-6, are pyrogenic. IL-6 is the last mediator of the cytokine cascade inducing the production

*Correspondence: jean-marc.cavaillon@pasteur.fr

Unit of Cytokines \& Inflammation, Department of Infection and Epidemiology, Institut Pasteur, 28 rue Dr Roux, F-75015 Paris, France of prostaglandin $E_{2}$ that acts on the thermoregulatory center within the hypothalamus. It is worth recalling that certain chemokines, such as IL-8 and macrophage inflammatory protein- 1 , can induce fever independently of any prostaglandin induction $[7,8]$. Thus, depending upon physiological responses, their relative contribution to fever could affect the efficiency of the antipyretic drugs that prevent prostaglandin production.

What is the physiological role of fever during infection? It is amusing to consider that the demonstration of the beneficial effect of fever was first achieved in cold-blooded animals. Kluger and colleagues showed that housing lizards infected with a bacteria at $42^{\circ} \mathrm{C}$ allowed them to survive, while all died when kept at $34^{\circ} \mathrm{C}$ [9]. Because mice instead undergo hypothermia and fail to maintain fever after bacterial infection, the same approach was performed. Klebsiella pneumoniae peritonitis infection was performed in mice housed at different ambient temperatures to allow a core temperature of 37.5 or $39.7^{\circ} \mathrm{C}[10]$. The bacterial load was exponential in the peritoneal cavity of mice with no fever and was under control in mice with fever. All mice with no fever died while $50 \%$ of those with fever survived. In another peritonitis model performed in sheep, the febrile response resulted in better respiratory function, lower blood lactate concentration and prolonged survival time [11].

In humans, numerous investigators have identified a better outcome among patients who displayed fever. For example, fever was among the factors associated with a decreased mortality in patients with Gram-negative bacteremia [12]. Hospitalized elderly patients who had community-acquired pneumonia with fever and leukocytosis were seven times less likely to die than those who did not show these symptoms [13]. Interestingly, in a study in which the outcome of sepsis was studied as a function of mitochondrial DNA haplogroups, the $\mathrm{H}$ haplogroup was found among the patients with the best survival. In this group, the most extreme core temperature observed within the first 24 hours was higher than in the non- $\mathrm{H}$ haplogroup [14].

In 1995 Shann already warned the medical community that the use of antipyretics in sepsis could be detrimental [15]. His claim was made with reference to numerous experimental animal models of severe infection in which 
the use of antipyretic drugs was shown to increase mortality. The work of Egi and colleagues nicely confirms this assertion [1]. It is interesting to point out that when the Kaplan-Meier curve is analyzed over 2 weeks, the outcome is significantly better among patients with fever above $37.5^{\circ} \mathrm{C}$ and below $39.4^{\circ} \mathrm{C}$ (the adjusted odds ratio for 14 days provides the same statistical significance; M Egi and colleagues, personal communication, February 2012). Because fever occurs early during the survey of the patients with sepsis, it makes sense that its effect is easier to identify within this period. The fact that, in contrast, high fever in patients without infection appears detrimental is also a key observation. In this study only a few patients without sepsis received acetaminophen [1]. Although there was no statistically significant difference, still $12.5 \%$ of survivors received nonsteroidal antiinflammatory drugs versus $2.8 \%$ among the nonsurvivors. Altogether, this study illustrates the need to detect as early as possible the occurrence of infection among ICU patients to consider the use of antipyretic drugs.

Finally, because elevated temperature results in a reduction of endotoxin tolerance [16] - a phenomenon that resembles the altered status observed in sepsis patients [17] - it would be of great interest to investigate whether fever is also associated with a less severe immunodysregulation. But let us leave William H Welch (1850 to 1934) to conclude. In 1888, he wrote: 'The feverproducing agents light the fire which consumes them. It is not incompatible with this conception of fever to suppose that the fire may prove injurious also to the patients, and may require the controlling hand of the physician' [18].

\section{Abbreviations}

IL, interleukin; TNF, tumor necrosis factor.

\section{Competing interests}

The author declares that he has no competing interests.

Published: 20 March 2012
References

1. Egi M, Kim JY, Suh GY, Koh Y, Nishimura N: Association of body temperature and antipyretic treatments with mortality of critically ill patients with and without sepsis: multi-centered prospective observational study. Crit Care 2012, 16:R33.

2. Davy J: Researches, Physiological and Anatomical. Volume I. London: Smith, Elder and Co.; 1839:161-198.

3. Becquerel A, Breschet G: Premier mémoire sur la chaleur animale. Ann Chimie Physique 1835, 59:113-136.

4. Menkin V: Chemical basis of fever. Science 1944, 100:337-338.

5. Bennett IL, Jr, Beeson PB: Studies on the pathogenesis of fever. II. Characterization of fever-producing substances from polymorphonuclear leukocytes and from the fluid of sterile exudates. J Exp Med 1953, 98:493-508.

6. Atkins E, Wood WB, Jr: Studies on the pathogenesis of fever. II. Identification of an endogenous pyrogen in the blood stream following the injection of typhoid vaccine. J Exp Med 1955, 102:499-516.

7. Zampronio AR, Souza GE, Silva CA, Cunha FQ, Ferreira SH: Interleukin-8 induces fever by a prostaglandin-independent mechanism. Am J Physiol 1994, 266(5 Pt 2):R1670-R1674.

8. Minano FJ, Sancibrian M, Vizcaino M, Paez X, Davatelis G, Fahey T, Sherry B, Cerami A, Myers RD: Macrophage inflammatory protein-1: unique action on the hypothalamus to evoke fever. Brain Res Bull 1990, 24:849-852.

9. Kluger MJ, Ringler DH, Anver MR: Fever and survival. Science 1975, 188:166-168.

10. Jiang $Q$, Cross AS, Singh IS, Chen TT, Viscardi RM, Hasday JD: Febrile core temperature is essential for optimal host defense in bacterial peritonitis. Infect Immun 2000, 68:1265-1270.

11. Su F, Nguyen ND, Wang Z, Cai Y, Rogiers P, Vincent JL: Fever control in septic shock: beneficial or harmful? Shock 2005, 23:516-520.

12. Bryant RE, Hood AF, Hood CE, Koenig MG: Factors affecting mortality of Gram-negative rod bacteremia. Arch Intern Med 1971, 127:120-128.

13. Ahkee S, Srinath L, Ramirez J: Community-acquired pneumonia in the elderly: association of mortality with lack of fever and leukocytosis. South Med J 1997, 90:296-298.

14. Baudouin SV, Saunders D, Tiangyou W, Elson JL, Poynter J, Pyle A, Keers S, Turnbull DM, Howell N, Chinnery PF: Mitochondrial DNA and survival after sepsis: a prospective study. Lancet 2005, 366:2118-2121.

15. Shann F: Antipyretics in severe sepsis. Lancet 1995, 345:338.

16. Lee CT, Zhong L, Mace TA, Repasky EA: Elevation in body temperature to fever range enhances and prolongs subsequent responsiveness of macrophages to endotoxin challenge. PLoS One 2012, 7:e30077.

17. Cavaillon JM, Adib-Conquy M: Bench-to-bedside review: Endotoxin tolerance as a model of leukocyte reprogramming in sepsis. Crit Care 2006, 10:233.

18. Welch WH: Cartwright lectures. The general pathology of fever. Boston Med Surg J 1888, 118:413-421.

doi:10.1186/cc11237

Cite this article as: Cavaillon JM: Good and bad fever. Critical Care 2012, 16:119. 